\title{
Expression of insulin target genes in skeletal muscle and adipose tissue in adult patients with growth hormone deficiency: effect of one year recombinant human growth hormone therapy
}

\author{
Y Khalfallah ${ }^{1,2,3}$, G Sassolas $^{3}$, F Borson-Chazot ${ }^{3}$, N Vega $^{1}$ \\ and $\mathbf{H}$ Vidal ${ }^{\mathbf{1}, 2}$ \\ ${ }^{1}$ INSERM U.449, René Laennec Faculty of Medicine, Lyon, France \\ ${ }^{2}$ Human Nutrition Research Center of Lyon, René Laennec Faculty of Medicine, Lyon, France \\ ${ }^{3}$ Nuclear Medicine Center, Neurology and Cardiology Hospital, Lyon, France \\ (Requests for offprints should be addressed to H Vidal, INSERM U.449, Faculté de Médecine RTH Laennec, Rue Guillaume Paradin, F-69372 Lyon Cédex 08 , \\ France; Email: vidal@laennec.univ-lyon1.fr)
}

\begin{abstract}
Our aim was to investigate the effects of one year recombinant human growth hormone (rhGH) therapy on the regulation by insulin of gene expression in muscle and adipose tissue in adults with secondary GH deficiency (GHD). Six GHD subjects without upper-body obesity were submitted to a 3-h euglycemic hyperinsulinemic clamp before and after one year of rhGH therapy. Muscle and abdominal subcutaneous adipose tissue biopsies were taken before and at the end of each clamp. The mRNA levels of insulin receptor, p85a-phosphatidylinositol-3 kinase (p85 $\alpha \mathrm{PI}-3 \mathrm{~K}$ ), insulin dependent glucose transporter (Glut4), hexokinase II, glycogen synthase, lipoprotein lipase (LPL) in muscle and in adipose tissue, hormone sensitive lipase and peroxisome proliferator-activated receptor $\gamma(\operatorname{PPAR} \gamma)$ in adipose tissue were quantified by RT-competitive PCR. One year treatment with rhGH (1.25 IU/day) increased plasma IGF-I concentrations (54 \pm 7 vs $154 \pm 11 \mathrm{ng} / \mathrm{ml}, P<0 \cdot 01$ ) but did not affect
\end{abstract}

insulin-stimulated glucose disposal rate measured during the hyperinsulinemic clamp (74 \pm 9 vs $85 \pm 5 \mu \mathrm{mol} / \mathrm{kg}$ free fat $\mathrm{mass} / \mathrm{min}$ ). Insulin significantly increased p $85 \alpha \mathrm{PI}-$ $3 \mathrm{~K}$, hexokinase II and Glut4 mRNA levels in muscle both before and after rhGH treatment. One year of GH therapy increased LPL mRNA levels in muscle ( $38 \pm 2$ vs $70 \pm 7$ amol $/ \mu \mathrm{g}$ total RNA, $P<0.05)$ and in adipose tissue ( $2490 \pm 260$ vs $4860 \pm 880 \mathrm{amol} / \mu \mathrm{g}$ total RNA, $P<0 \cdot 05)$, but did not change the expression of the other mRNAs. We conclude from this study that GH therapy did not alter whole body insulin sensitivity and the response of gene expression to insulin in skeletal muscle of adult GHD patients, but it did increase LPL expression in muscle and adipose tissue. This result could be related to the documented beneficial effect of GH therapy on lipid metabolism.

Journal of Endocrinology (2001) 171, 285-292

\section{Introduction}

Insulin sensitivity has been reported to be impaired in some hypopituitary patients with growth hormone deficiency (GHD) who receive replacement therapy for other pituitary deficits (O'Neal et al. 1994, Hew et al. 1996, Hwu et al. 1997, Carroll et al. 1998, Christopher et al. 1998, Alford et al. 1999). Using the euglycemic hyperinsulinemic clamp methodology, some investigators have found a reduction in insulin-stimulated glucose utilization in GHD patients compared with matched control subjects (Hew et al. 1996, Christopher et al. 1998). However, it has also been reported that in adults with GHD, glucose turnover is normal when expressed per lean body mass (Salomon et al. 1994). It is also important to note that reduced insulin sensitivity was mainly observed in obese GHD patients (Page et al. 1994), suggesting that obesity, rather than GHD per se, might be responsible for insulin resistance. In addition to obesity, other factors associated with GHD may contribute to alterations in insulin sensitivity such as increased visceral fat mass (Ho et al. 1996), sedentariness (Jorgensen et al. 1996) and the doses of thyroxine (Jap et al. 1989) and corticosteroids (Horber et al. 1991) used during replacement therapy.

The effect of growth hormone $(\mathrm{GH})$ replacement on insulin sensitivity is also controversial. Several studies have shown that insulin sensitivity is either reduced (Beshyah et al. 1995, Weaver et al. 1995), or unchanged (Fowelin et al. 1993, Christopher et al. 1998, Bulow \& Erfurth 1999) during recombinant human (rh) GH treatment. This reduction may be a transitory short-term phenomenon, as long-term treatment did not modify insulin 
Table 1 Individual characteristics of GHD patients and effect of GH treatment on plasma IGF-I concentration

\begin{tabular}{|c|c|c|c|c|c|c|c|}
\hline & \multirow{2}{*}{$\begin{array}{l}\text { Replacement } \\
\text { therapy }\end{array}$} & \multirow[b]{2}{*}{ Sex } & \multirow{2}{*}{$\begin{array}{l}\text { Age } \\
(\mathrm{yr})\end{array}$} & \multirow{2}{*}{$\begin{array}{l}\text { Years after } \\
\text { diagnosis }\end{array}$} & \multirow{2}{*}{$\begin{array}{l}\text { GH dose } \\
\text { (IU/day) }\end{array}$} & \multicolumn{2}{|l|}{$\begin{array}{l}\text { IGF-I } \\
(\mu \mathrm{g} / \mathrm{l})\end{array}$} \\
\hline & & & & & & $-\mathrm{GH}$ & $+\mathrm{GH}$ \\
\hline $\begin{array}{l}\text { Patient no. } \\
1\end{array}$ & $\mathrm{CS}+\mathrm{GS}$ & $\mathrm{F}$ & 33 & 8 & 2 & 55 & 164 \\
\hline 2 & $\mathrm{CS}+\mathrm{GS}+\mathrm{T}$ & $\mathrm{F}$ & 27 & 4 & 1 & 44 & 130 \\
\hline 3 & $\mathrm{CS}+\mathrm{GS}+\mathrm{T}$ & $\mathrm{F}$ & 39 & 5 & 1 & 49 & 119 \\
\hline 4 & $\mathrm{CS}+\mathrm{GS}+\mathrm{T}$ & M & 50 & 3 & $1 \cdot 5$ & 84 & 183 \\
\hline 5 & $\mathrm{CS}+\mathrm{GS}$ & M & 39 & 1 & 2 & 59 & 183 \\
\hline 6 & GS & M & 45 & 14 & $0 \cdot 5$ & 32 & 146 \\
\hline
\end{tabular}

CS, corticosteroids; GS, gonadal steroids; $\mathrm{T}$, thyroxine; $-\mathrm{GH}$, at baseline; $+\mathrm{GH}$, after 12 months of $\mathrm{GH}$ treatment. IGF-I $(\mu \mathrm{g} / \mathrm{l})$ : normal values for age (yr) (Kratzsch et al. 1993): 20-30=195; 31-40=153; $41-50=120$.

sensitivity (Fowelin et al. 1993, Hew et al. 1996). In one study, however, a normalization of insulin sensitivity was observed after 1 year of rhGH treatment in insulinresistant adult GHD subjects (Hwu et al. 1997). It has been proposed that this effect could be mainly related to the reduction of total body fat (Hwu et al. 1997).

Few studies have investigated the possible mechanisms of the proposed alteration in insulin sensitivity in GHD. It has recently been reported that in adult GHD patients with decreased insulin-mediated glucose utilization, a reduction of glycogen synthase activity in the muscle may be implicated in the impaired insulin action (Hew et al. 1996, Christopher et al. 1998). The same group also demonstrated that 1 year of $\mathrm{GH}$ replacement therapy did not restore this defect (Christopher et al. 1998).

In the present study, as part of a large multicenter rhGH trial in GHD (Borson-Chazot et al. 1999), we have determined the expression profile of eight genes coding for proteins involved in insulin action in skeletal muscle and adipose tissue and have studied the regulation of the expression of these genes by insulin using the euglycemic hyperinsulinemic clamp method (DeFronzo et al. 1979). This molecular approach has been performed to characterize GHD patients and the effect of GH replacement therapy on insulin sensitivity at the gene expression level. We have aimed to verify whether the regulation by insulin of gene expression may be altered in GHD patients in a similar way as has been reported in other groups of insulin-resistant subjects such as type 2 diabetic patients (Andersen et al. 1993, Andreelli et al. 1999).

\section{Subjects and Methods}

\section{Subjects}

Six patients ( 3 men and 3 women), participating in a multicentric therapeutic trial on rhGH (Pharmacia, Stockholm, Sweden), were enrolled in the present study
(Table 1). These patients were GH deficient because of pituitary disorders (pituitary adenoma in five patients and craniopharyngioma in one). All presented a multiple pituitary deficit and had been on stable replacement therapy for at least 2 years. None of these subjects had been previously treated with $\mathrm{GH}$ or for acromegaly. The criterion for the diagnosis of GHD was a GH peak below $3 \mu \mathrm{g} / 1$ during an insulin-induced hypoglycemia test (glycemia $<2 \cdot 2 \mathrm{mmol} / \mathrm{l}$ ). In the six investigated patients the GH peak was below $1 \mu \mathrm{g} / 1$. A second GH stimulating test (glucagon-propranolol or GH-releasing hormone) confirmed the diagnosis for each patient. Both tests were performed after the age of 20 years and within the 5 years preceding the inclusion in the study. The basal plasma insulin-like growth factor-I (IGF-I) concentrations of the subjects were lower than normal age-adjusted values (Table 1 and Kratzsch et al. 1993). None of the subjects had a personal history of diabetes or hypertension. Their ages ranged from 27 to 50 years (Table 1). Their mean body mass index (BMI) was $24.6 \mathrm{~kg} / \mathrm{m}^{2}$, with a waist-tohip ratio lower than 0.80 for the women and 0.95 for the men (Table 1) indicating that none of the subjects was characterized by upper-body obesity.

\section{Study design}

The study was approved by the Ethical Committee of Hospices Civils de Lyon (France) and was performed in accordance with the Helsinki guidelines. The objective of the study was explained to the patients and their written consent was obtained. The subjects were treated by daily subcutaneous injection of rhGH (Genotonorm, Pharmacia) at a dose that was adapted on an individual basis so as to maintain IGF-I concentrations in the 95 percentile of the normal range using an age-adjusted reference (legend of Table 1 and Kratzsch et al. 1993). For each patient the GH dose that was used is indicated in Table 1 and never exceeded 2 IU/day (range 0.52 IU/day). 
A euglycemic hyperinsulinemic clamp to assess insulin sensitivity, and tissue biopsies to study the regulation of specific mRNA expression, were performed before $(-\mathrm{GH})$ and after $(+\mathrm{GH})$ one year of rhGH treatment. In addition, body composition was estimated by bioelectric impedancemetry (BIA 101, Eugedia, Paris, France) before and after one year of rhGH treatment.

\section{Euglycemic hyperinsulinemic clamp study}

All studies were performed in the morning after an overnight fast and at least $10 \mathrm{~h}$ after the last $\mathrm{GH}$ injection. Basal glucose turnover rate was determined by dilution tracer methodology using a primed 6,6 [ $\left.{ }^{2} \mathrm{H} 2\right]$ glucose (Eurisotop, St Aubain, France) infusion $(0 \cdot 11 \mu \mathrm{mol} / \mathrm{kg}$ per min) for $2 \mathrm{~h}$ as described previously (Laville et al. 1996). Then a 3-h euglycemic hyperinsulinemic clamp was started by the infusion of insulin (Actrapid Novo, Copenhagen, Denmark) at a rate of $450 \mathrm{pmol} / \mathrm{m}^{2}$ per min (Laville et al. 1996). Any decrease in blood glucose was prevented by adapted infusion of $20 \%$ glucose solution (Aguettant, Lyon, France).

\section{Tissue biopsies}

Muscle samples $(43 \pm 3 \mathrm{mg}$ wet $\mathrm{wt}, n=24)$ were taken under local anesthesia by per cutaneous biopsies of the vastus lateralis muscle using Weil Blakesley pliers as previously described (Laville et al. 1996). Abdominal subcutaneous adipose tissue was aspirated from the periumbilical area through a $2.3 \mathrm{~mm}$ (13 gauge) needle under local anesthesia (Vidal et al. 1996). To study the regulation of gene expression by insulin (Laville et al. 1996, Andreelli et al. 1999), both muscle and adipose tissue biopsies were taken before the clamp and after the 3 hours of the euglycemic hyperinsulinemic clamp. Tissue samples were immediately frozen in liquid nitrogen and stored at $-80{ }^{\circ} \mathrm{C}$ until analysis. For one subject (\#2), biopsies were obtained only in the basal state, both before and during GH therapy.

\section{Indirect calorimetry}

To estimate lipid and glucose oxidation rates, respiratory exchange measurements were carried out during the last $30 \mathrm{~min}$ of the basal period and during the last hour of the euglycemic hyperinsulinemic clamp. Measurements were made using a computerized follow-through canopy gasanalyzer system (Deltatrac Metabolic Monitor, Datex, Helsinki, Finland). Total carbohydrate and lipid oxidation rates were calculated according to the published equations (Ferrannini 1988).

\section{Analytical procedures}

For the determination of metabolite and hormone concentrations and of 6,6 [ $\left.{ }^{2} \mathrm{H} 2\right]$ glucose isotopic enrichment, blood samples were drawn every $10 \mathrm{~min}$ during the last $30 \mathrm{~min}$ of the basal period and during the last hour of the hyperinsulinemic clamp. Plasma metabolites were measured using enzymatic methods and C-peptide and insulin concentrations using radioimmunoassays. Plasma isotopic enrichment of $6,6\left[{ }^{2} \mathrm{H} 2\right]$ glucose was determined by gas chromatography-mass spectrometry (5971 MSD, Hewlett-Packard, Paolo Alto, CA, USA) as described (Beylot et al. 1986). Basal glucose turnover rate was calculated using steady-state equations.

\section{Total RNA preparation}

Frozen muscle samples were powdered in liquid nitrogen, and total RNA was prepared using guanidium thiocyanate and phenol/chloroform extraction followed by alcohol precipitation (Chomczynski \& Sacchi 1987). The preparation of total RNA from adipose tissue was performed using the RNeasy mini kit (Qiagen, Courtaboeuf, France). The mean size of fat tissue that was used for total RNA preparation was $90 \pm 4 \mathrm{mg}$ wet wt $(n=24)$. Yields of total RNA were $35 \pm 3 \mu \mathrm{g} / 100 \mathrm{mg}$ wet wt muscle and $1 \cdot 4 \pm 0.1 \mu \mathrm{g} / 100 \mathrm{mg}$ wet wt adipose tissue, and were similar to samples taken before or after the growth hormone therapy. The $260 \mathrm{~nm}$ to $280 \mathrm{~nm}$ absorption ratios were always between $1 \cdot 8$ and $2 \cdot 1$. Total RNA solutions were stored at $-80^{\circ} \mathrm{C}$.

\section{Quantification of messenger RNAs}

The mRNA concentrations of insulin receptor (IR), p85 $\alpha$-phosphatidylinositol-3 kinase (p85aPI-3K), insulin dependent glucose transporter (Glut4), hexokinase II (HKII), glycogen synthase (GS) and lipoprotein lipase (LPL) in skeletal muscle and in adipose tissue, hormone sensitive lipase (HSL) and peroxisome proliferatoractivated receptor $\gamma(\operatorname{PPAR} \gamma)$ in adipose tissue were quantified by reverse transcription followed by competitive polymerase chain reaction (RT-cPCR) (Auboeuf \& Vidal 1997). The conditions of the assays, the sequences of the primers and the validation of the method have been described previously (Laville et al. 1996, Auboeuf et al. 1997, Andreelli et al. 2000). To accurately determine the effect of rhGH treatment on gene expression, total RNA of the four muscle or adipose tissue biopsies from the same individual were prepared simultaneously, and the assays of a given mRNA were made in parallel, in the same run of PCR with the same working solutions of competitors. The results are expressed in amol/ $\mu \mathrm{g}$ total RNA.

\section{Statistical analysis}

Nonparametric Wilcoxon's test for paired values was used when comparing mRNA levels before and during rhGH 
Table 2 Effect of GH treatment on body composition

\begin{tabular}{|c|c|c|c|c|c|c|c|c|}
\hline & \multicolumn{2}{|l|}{$\begin{array}{l}\text { Weight } \\
(\mathrm{kg})\end{array}$} & \multicolumn{2}{|l|}{$\begin{array}{l}\text { BMI } \\
\left(\mathrm{kg} / \mathrm{m}^{2}\right)\end{array}$} & \multicolumn{2}{|c|}{$\begin{array}{l}\text { Body fat } \\
(\%)\end{array}$} & \multicolumn{2}{|l|}{$\mathrm{W} / \mathrm{H}$ ratio } \\
\hline & $-\mathrm{GH}$ & $+\mathrm{GH}$ & $-\mathrm{GH}$ & $+\mathrm{GH}$ & $-\mathrm{GH}$ & $+\mathrm{GH}$ & $-\mathrm{GH}$ & $+\mathrm{GH}$ \\
\hline 2 & 60 & 63 & $24 \cdot 7$ & $25 \cdot 9$ & 38 & 39 & $0 \cdot 80$ & $0 \cdot 83$ \\
\hline 3 & 62 & 64 & $22 \cdot 2$ & $22 \cdot 9$ & 34 & 35 & $0 \cdot 70$ & 0.75 \\
\hline 6 & 89 & 90 & $29 \cdot 1$ & $29 \cdot 4$ & 40 & 38 & 0.93 & $0 \cdot 94$ \\
\hline Mean \pm S.E.M. & $71 \cdot 3 \pm 7 \cdot 6$ & $69 \cdot 3 \pm 8 \cdot 2$ & $24 \cdot 7 \pm 1 \cdot 9$ & $24 \cdot 6 \pm 2 \cdot 1$ & $33 \pm 2$ & $32 \pm 2$ & $0.83 \pm 0.04$ & $0 \cdot 84 \pm 0 \cdot 03$ \\
\hline
\end{tabular}

$-\mathrm{GH}$, at baseline; $+\mathrm{GH}$, after 12 months of $\mathrm{GH}$ treatment; $\mathrm{W} / \mathrm{H}$, waist-to-hip ratio.

treatment or before and during hyperinsulinemic clamp. The threshold for significance was set at $P<0 \cdot 05$. Data in text and figures are presented as means \pm s.E.M.

\section{Results}

Effect of GH replacement on anthropometric, hormonal and metabolic parameters

As classically observed, the six GHD subjects were characterized by higher body fat mass (Table 2) than the theoretical values that can be calculated from their sex, age and BMI $(33 \pm 2 \%$ vs $23 \pm 2 \%)$. Before rhGH treatment, the patients had normal plasma concentrations of glucose, insulin, non-esterified fatty acids (NEFA) and triglyceride (Table 3) when compared with our previously reported values for age-matched healthy subjects (Laville et al. 1996, Andreelli et al. 1999). Whole body glucose disposal rate both in the basal state and during the hyperinsulinemic clamp was normal when refered to the free fat mass (FFM) (Table 3) or the body surface area of the subjects $\left(420 \pm 30\right.$ and $2160 \pm 180 \mu \mathrm{mol} / \mathrm{m}^{2}$ per min, basal and during the clamp respectively). In independent studies with healthy lean subjects but using the same hyperinsulinemic clamp method (Andreelli et al. 1999, 2000), we have found values of $460 \pm 30 \mu \mathrm{mol} / \mathrm{m}^{2}$ per min for the basal period and $1900 \pm 150 \mu \mathrm{mol} / \mathrm{m}^{2}$ per min during the clamp. After one year of rhGH treatment, a threefold increase in plasma IGF-I concentrations was observed (54 \pm 7 vs $154 \pm 11 \mu \mathrm{g} / 1, P<0 \cdot 01$, Table 1 ). There was no change in body weight, percentage of body fat or waistto-hip ratio (Table 2) during treatment. After an overnight fast, glycemia, insulinemia, C-peptide $(1.2 \pm 0.5 \mathrm{vs}$ $1 \cdot 0 \pm 0 \cdot 4 \mu \mathrm{g} / \mathrm{l}$, after vs during $\mathrm{rhGH}$ treatment), NEFA, triglyceride and $\beta$-hydroxybutyrate concentrations were unchanged by rhGH treatment (Table 3). Glucose turnover rates (Table 3), glucose oxidation rates $(8 \cdot 9 \pm 2$ vs $9 \cdot 8 \pm 0.7 \mu \mathrm{mol} / \mathrm{kg}$ FFM $/ \mathrm{min}$, before vs during treatment), lipid oxidation rates $(1 \cdot 1 \pm 0 \cdot 2$ vs $1 \cdot 1 \pm 0 \cdot 1 \mu \mathrm{mol} /$ $\mathrm{kg} \mathrm{FFM} / \mathrm{min}$, before vs during treatment) and protein oxidation rates $(1 \cdot 0 \pm 0.1 \mathrm{vs} 0 \cdot 8 \pm 0 \cdot 1 \mu \mathrm{mol} / \mathrm{kg}$ FFM/ min, before vs during treatment) were also not modified. Resting metabolic rate was the same before and during rhGH treatment $(1490 \pm 130$ vs $1500 \pm 140 \mathrm{kcal} /$ day, before vs after $\mathrm{rhGH}$ ). Finally, one year of rhGH treatment did not significantly modify insulin-stimulated glucose disposal rates and the different metabolic parameters that were measured during the euglycemic hyperinsulinemic clamp (Table 3).

Table 3 Metabolic and hormonal variables before (Basal) and during the last $30 \mathrm{~min}$ of the euglycemic hyperinsulinemic clamp (Infusion), at baseline $(-\mathrm{GH})$ and after 12 months of $\mathrm{GH}$ treatment $(+\mathrm{GH})$. Glucose turnover rate was determined at basal and glucose infusion rate during euglycemic hyperinsulinemic clamp, both at $-\mathrm{GH}$ and $+\mathrm{GH}$ periods

\begin{tabular}{|c|c|c|}
\hline \multicolumn{3}{|l|}{ Insulinemia (pmol/l) } \\
\hline Basal & $31 \pm 6$ & $36 \pm 9$ \\
\hline Infusion & $1412 \pm 161^{*}$ & $1215 \pm 131^{*}$ \\
\hline \multicolumn{3}{|l|}{ Glycemia (mmol/l) } \\
\hline Basal & $4 \cdot 7 \pm 0 \cdot 3$ & $4 \cdot 9 \pm 0 \cdot 2$ \\
\hline Infusion & $4 \cdot 7 \pm 0 \cdot 2$ & $4 \cdot 7 \pm 0 \cdot 4$ \\
\hline \multicolumn{3}{|l|}{ Triglyceride $(\mu \mathrm{mol} / \mathrm{l})$} \\
\hline Basal & $730 \pm 140$ & $780 \pm 104$ \\
\hline Infusion & $540 \pm 107$ & $578 \pm 66$ \\
\hline \multicolumn{3}{|l|}{$\mathrm{NEFA}(\mu \mathrm{mol} / \mathrm{l})$} \\
\hline Basal & $430 \pm 32$ & $380 \pm 52$ \\
\hline Infusion & $43 \pm 6^{*}$ & $36 \pm 6^{*}$ \\
\hline \multicolumn{3}{|l|}{$\beta$-Hydroxybutyrate $(\mu \mathrm{mol} / \mathrm{l})$} \\
\hline Basal & $75 \pm 16$ & $94 \pm 20$ \\
\hline Infusion & $25 \pm 3^{*}$ & $28 \pm 6^{*}$ \\
\hline \multicolumn{3}{|l|}{ Glucose clamp study } \\
\hline $\begin{array}{l}\text { Basal glucose turnover rate } \\
(\mu \mathrm{mol} / \mathrm{kgFFM} / \mathrm{min})\end{array}$ & $16 \pm 1$ & $17 \pm 1$ \\
\hline $\begin{array}{l}\text { Glucose infusion rate } \\
(\mu \mathrm{mol} / \mathrm{kgFFM} / \mathrm{min})\end{array}$ & $85 \pm 5$ & $74 \pm 9$ \\
\hline
\end{tabular}

${ }^{*} P<0 \cdot 001$ infusion vs basal. 


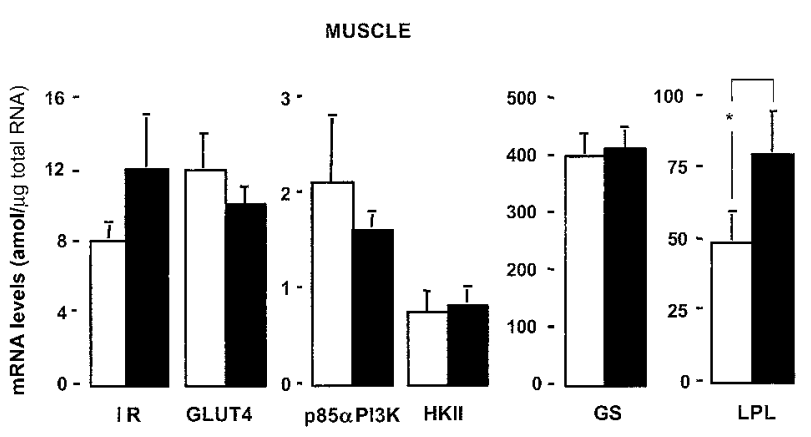

ADIPOSE TISSUE
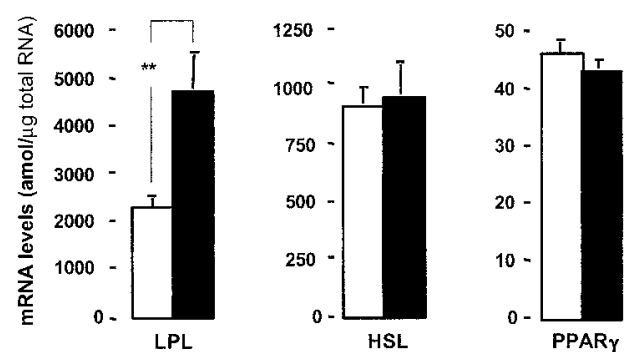

Figure 1 Expression profiles of the target mRNAs in tissues of GHD patients. Concentrations of the target mRNAs were determined by RT-CPCR in vastus lateralis muscle and in abdominal subcutaneous adipose tissue before (open bars) and after (closed bars) 12 months of rhGH treatment. Data are means \pm S.E.M., $n=6$; ${ }^{*} P=0 \cdot 046$ and ${ }^{*} P=0 \cdot 027$. Values of mRNA levels (mean \pm S.D.) determined with the same methodology in tissues of 9 healthy lean control subjects (Lefebvre et al., 1998, Andreelli et al., 2000) were: $14 \pm 5 \mathrm{amol} / \mu \mathrm{g}$ total RNA for IR; $10 \pm 3$ for Glut $4 ; 6 \pm 3$ for p85aPI-3K; $1 \pm 0 \cdot 7$ for HKII; $333 \pm 131$ for GS; $44 \pm 16$ for LPL in muscle and $1370 \pm 160$ for LPL in adipose tissue; $460 \pm 100$ for HSL; and $42 \pm 8$ for PPAR $\gamma$.

\section{Effect of rhGH replacement on skeletal muscle and adipose tissue gene expression}

The absolute levels of the target mRNAs, determined by $\mathrm{RT}-\mathrm{cPCR}$, in total RNA preparations from vastus lateralis muscle and from abdominal subcutaneous adipose tissue are shown in Fig. 1. In the basal state, after an overnight fast, the expression profiles of the mRNAs were similar to those we have previously found in control subjects using the same RT-cPCR based assays (legend of Fig. 1 and Lefebvre et al. 1998, Andreelli et al. 2000). In skeletal muscle, glycogen synthase mRNA was expressed at the highest level whereas HKII mRNA level was low. The mRNA levels of p85aPI-3K seemed lower in GHD patients $(2.1 \pm 0.7 \mathrm{amol} / \mu \mathrm{g}$ total RNA) than in healthy control subjects $(6 \pm 3 \mathrm{amol} / \mu \mathrm{g}$ total RNA) (Andreelli et al. 2000). In adipose tissue, LPL was expressed at the highest levels (Fig. 1). HSL mRNA levels seemed to be higher in GHD patients (914 $\pm 87 \mathrm{amol} / \mu \mathrm{g}$ total RNA) than in healthy control subjects $(460 \pm 100 \mathrm{amol} / \mu \mathrm{g}$ total RNA) (Lefebvre et al. 1998). After one year of $\mathrm{rhGH}$ treatment, the expression levels of $\operatorname{IR}(8 \cdot 4 \pm 1 \cdot 4$ vs $12 \pm 3$ $\mathrm{amol} / \mu \mathrm{g}$ total RNA), Glut4 (12 $\pm 2 \mathrm{vs} 10 \pm 1 \mathrm{amol} / \mu \mathrm{g}$ total RNA), p85aPI-3K (2.1 \pm 0.7 vs $1.6 \pm 0.2 \mathrm{amol} / \mu \mathrm{g}$ total RNA), HKII $(0.7 \pm 0.2$ vs $0.8 \pm 0.2 \mathrm{amol} / \mu \mathrm{g}$ total RNA) and GS $(397 \pm 40$ vs $340 \pm 77 \mathrm{amol} / \mu \mathrm{g}$ total RNA) were not modified in skeletal muscle. In contrast, LPL gene expression was significantly increased by rhGH treatment $(48 \pm 11$ vs $79 \pm 15 \mathrm{amol} / \mu \mathrm{g}$ total RNA, $P=$ 0.046) (Fig. 1). In adipose tissue also, GH replacement produced a marked increase in LPL mRNA levels $(2270 \pm 216$ vs $4712 \pm 802 \mathrm{amol} / \mu \mathrm{g}$ total RNA, $P=$ 0.027) without affecting HSL (914 \pm 87 vs $951 \pm 159$ $\mathrm{amol} / \mu \mathrm{g}$ total RNA) and total PPAR $\gamma(46 \pm 8$ vs $43 \pm 7$ $\mathrm{amol} / \mu \mathrm{g}$ total RNA) expression (Fig. 1). The changes in LPL mRNA expression upon rhGH treatment were not associated with modification in plasma triglyceride or NEFA concentrations (data not shown).

Regulation of muscle gene expression by insulin in GHD patients before and during rhGH treatment

We and others have demonstrated that insulin upregulates the expression of p85aPI-3K (Laville et al. 1996, Andreelli et al. 1999), Glut4 (Schalin-Jantti et al. 1994, Laville et al. 1996) and HKII (Pendergrass et al. 1998) in human skeletal muscle. We therefore investigated whether the response of these three genes to short-term insulin infusion was altered in GHD patients. Figure 2 clearly shows that insulin infusion increased the mRNA levels of p $85 \alpha \mathrm{PI}-3 \mathrm{~K}$ $(P=0 \cdot 043)$, Glut4 $(P=0 \cdot 079)$ and HKII $(P=0 \cdot 043)$ in the muscle of GHD patients. The mRNA levels of Glut4 clearly increased in four subjects and did not change in one. The response to insulin of the three mRNAs was also found after one year of rhGH treatment $(P=0 \cdot 043$, Fig. 2).

\section{Discussion}

We have investigated the effect of one year rhGH replacement therapy on the regulation by insulin of the expression of specific key genes in muscle and adipose tissue in a group of adult GHD patients. Growth hormone deficiency has been associated with insulin resistance in some adult patients (O’Neal et al. 1994, Hew et al. 1996, Hwu et al. 1997, Carroll et al. 1998, Christopher et al. 1998, Alford et al. 1999). However, depending on the studied populations and also on the method used to estimate insulin sensitivity, the presence of insulin resistance in adult GHD is still a controversial issue. Indeed, some authors have found a reduction (O'Neal et al. 1994, Hew et al. 1996, Hwu et al. 1997, Christopher et al. 1998, Alford et al. 1999), while others have found a normal (Page et al. 1994, Salomon et al. 1994) insulin sensitivity in GHD patients. Obesity, increased truncal fat mass, hormonal replacement therapy and other confounding factors may influence insulin sensitivity, and also unravel a putative 

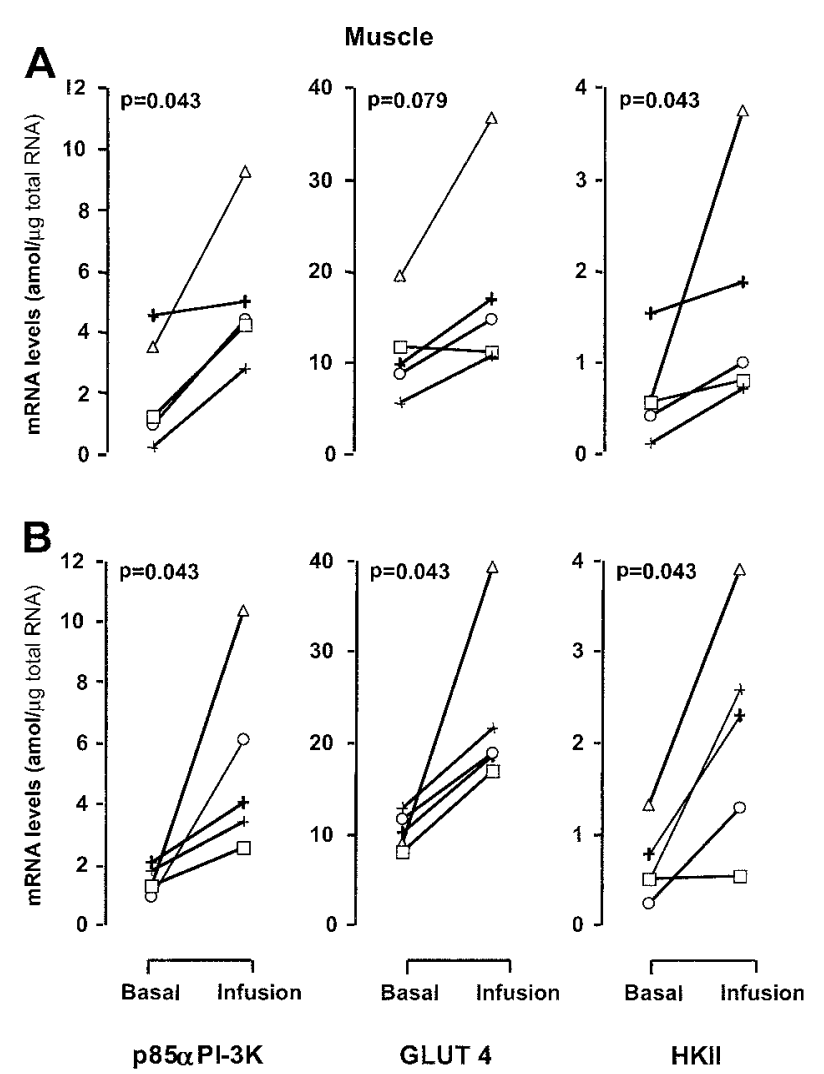

Figure 2 Insulin-induced changes in the expression levels of p $85 \alpha \mathrm{PI}-3 \mathrm{~K}$, Glut 4 and HKII in skeletal muscle of GHD patients. The concentrations of the target mRNA was measured in the basal state (Basal) and at the end of a 3-h hyperinsulinemic euglycemic clamp (Infusion) both before (A) and during (B) rhGH treatment. After clamp biopsies were not available for one patient.

direct role of the deficiency in GH. Nevertheless, because insulin resistance is an important cardiovascular risk factor (Reaven 1988) and because GHD patients are at high risk for cardiovascular disease (Rosen \& Bengtsson 1990), it is of great importance to define clearly whether insulin action is impaired in GHD patients and whether replacement therapy with $\mathrm{GH}$ affects insulin response in vivo.

We have investigated GHD subjects with waist-to-hip ratios lower than 0.80 for the women and 0.95 for the men to limit the influence of upper-body obesity as a confounding factor for insulin resistance (Krotkiewski et al. 1990, Seidell et al. 1990). In this group of patients, fasting plasma concentrations of insulin, C-peptide, glucose, NEFA and triglycerides were normal when compared with data obtained in age-, sex- and BMI-matched healthy subjects (Laville et al. 1996, Andreelli et al. 1999, 2000). In addition, using the gold standard for measuring insulin action, the euglycemic hyperinsulinemic clamp method, we found that these patients had a normal insulin sensitivity of whole-body glucose metabolism. This result contrasted with most of the previous reports (O'Neal et al. 1994, Hew et al. 1996, Hwu et al. 1997, Christopher et al. 1998, Alford et al. 1999) that showed a reduced insulin sensitivity in different groups of adult GHD. One could thus suggest that upper-body obesity may be one of the causal parameters of insulin resistance in GHD (Page et al. 1994). Further studies are needed to verify this hypothesis by comparing insulin sensitivity in adult GHD patients with and without obesity.

One year of rhGH replacement therapy, at an average dose of 1.25 IU/day, significantly increased plasma IGF-I concentrations to normal levels. In a larger cohort, we have previously reported that the same rhGH treatment has beneficial effects on intima-media thickness and on plasma lipid and lipoprotein profile and was associated with a significant reduction in the fat mass of the subjects (Borson-Chazot et al. 1999). Here, the anthropometric parameters of the six GHD patients were not significantly affected after one year of rhGH treatment although it should be noted that four out of the six patients showed a slight decrease in percentage body fat, but the difference did not reach significance. Regarding the effects of rhGH treatment on the parameters of glucose metabolism, neither fasting plasma glucose, nor insulin or c-peptide concentrations, nor insulin-stimulated glucose disposal rate during the clamp were modified after one year of rhGH treatment. These results indicated, however, that rhGH therapy, at the low doses that were used, has no deleterious effect on glucose metabolism.

Little is known about the influence of GH deficiency and $\mathrm{GH}$ replacement therapy on gene expression in muscle and adipose tissue. It has recently been reported that insulin-resistant GHD patients show a reduced stimulation by insulin of skeletal muscle glycogen synthase activity (Hew et al. 1996, Christopher et al. 1998), a defect which is reminiscent of that observed in insulin-resistant type 2 diabetic patients (Damsbo et al. 1991). This defect was not corrected by rhGH treatment (Christopher et al. 1998). In the present study we report, for the first time, the expression profiles of eight genes coding important metabolic enzymes and proteins in skeletal muscle and in adipose tissue of GHD patients. The mRNA levels of p $85 \alpha \mathrm{PI} 3-\mathrm{K}$ seemed to be reduced in GHD muscle (Andreelli et al. 2000) and the expression of the HSL seemed to be higher in GHD adipose tissue than in controls (Lefebvre et al. 1998). However, because the quantitation of the target mRNAs were not made at the same time and in parallel runs of RT-cPCR in GHD and in control subjects, and also because the number of GHD patients was low, we prefered not to draw any definite comparative conclusions. We may, however, conclude that there was no major abnormality in the relative levels of the different target mRNAs in the tissues of GHD when compared with those we have previously reported in healthy lean control subjects (Lefebvre et al. 1998, Andreelli et al. 2000). Interestingly, one year of rhGH 
treatment increased significantly the expression of LPL mRNA both in muscle and in adipose tissue without affecting the expression of genes involved in insulin action in muscle or HSL and PPAR $\gamma$ mRNA levels in adipose tissue.

Adipose tissue and skeletal muscle are the main sources of LPL, a key enzyme in the regulation of the flux of fatty acids. Numerous studies have demonstrated that GH can participate in the regulation of LPL expression and activity (Richelsen 1999). In rats, hypophysectomy reduced LPL activity in muscle, and rhGH treatment increased LPL activity in heart and in gastrocnemius muscle (Oscarsson et al. 1999). It has also been demonstrated that GH can stimulate LPL gene transcription in vitro in a time- and dose-dependent manner (Francis et al. 1993). However, in obese subjects with (Oscarsson et al. 1996) or without (Richelsen et al. 1994) GHD, treatment with GH resulted in a reduction in adipose tissue LPL activity without a change in mRNA levels. In obese GHD patients treated for 4 months with GH, Richelsen (1999) found no effect on skeletal muscle LPL activity or mRNA level. This discrepancy with our findings may result from differences in patient selection (obese vs nonobese GHD), in the doses of GH used (markedly higher in Oscarsson et al. 1996 and Richelsen et al. 1994 than in our work) as well as in the associated treatments that can affect LPL gene regulation (Fried et al. 1993). Despite the increased LPL mRNA expression, triglyceride concentrations did not change significantly during rhGH treatment in the investigated group of patients. This result suggests that the observed upregulation of LPL mRNA may not be associated with an increase in LPL activity in the blood vessels. Further investigations are thus required to verify whether the change in LPL expression could have a role in the previously documented beneficial effect of rhGH treatment on lipoprotein metabolism (Carroll et al. 1998, Christopher et al. 1998).

In insulin-resistant type 2 diabetes mellitus patients, defects in the acute regulation by insulin of the expression of some important genes have been documented in skeletal muscle (Andersen et al. 1993, Andreelli et al. 1999). We found in this work that insulin up-regulates p $85 \alpha \mathrm{PI} 3-\mathrm{K}$, Glut4 and HKII mRNA expression in the muscle of GHD patients. One year of treatment with rhGH did not modify the expression of these three genes in response to insulin infusion. Therefore, the regulation by insulin of important genes is not altered in the skeletal muscle of GHD patients.

In conclusion, our study suggests that adult GHD patients without upper-body obesity are not insulin resistant and shows that they have a normal response of gene expression to insulin in skeletal muscle. Growth hormone treatment $(1.25 \mathrm{IU} /$ day) for one year, which increases plasma IGF-I levels, induces LPL mRNA expression both in skeletal muscle and in subcutaneous adipose tissue without affecting whole body insulin sensitivity and the response of gene expression to insulin in muscle.

\section{Acknowledgements}

We thank C Urbain, M Odeon and J Peyrat for excellent technical assistance, and all the patients for their kind contribution.

\section{References}

Alford FP, Hew FL, Christopher MC \& Rantzau C 1999 Insulin sensitivity in growth hormone $(\mathrm{GH})$-deficient adults and effect of GH replacement therapy. Journal of Endocrinological Investigation 22 28-32.

Andersen PH, Lund S, Vestergaard H, Junker S, Kahni BB \& Pedersen O 1993 Expression of the major insulin regulatable glucose transporter (GLUT4) in skeletal muscle of noninsulindependent diabetic patients and healthy subjects before and after insulin infusion. Journal of Clinical Endocrinology and Metabolism 77 27-32.

Andreelli F, Laville M, Ducluzeau PH, Vega N, Vallier P, Khalfallah Y, Riou JP \& Vidal H 1999 Defective regulation of phosphatidylinositol3-kinase gene expression in skeletal muscle and adipose tissue of noninsulin-dependent diabetes mellitus patients. Diabetologia 42 358-364.

Andreelli F, Laville M, Vega N, Riou J-P \& Vidal H 2000 Regulation of gene expression during severe caloric restriction: lack of induction of $\mathrm{p} 85 \alpha$ phosphatidylinositol-3-kinase mRNA in skeletal muscle of patients with type II (non-insulin-dependent) diabetes mellitus. Diabetologia 43 356-363.

Auboeuf D \& Vidal H 1997 The use of the reverse transcriptioncompetitive polymerase chain reaction to investigate the in vivo regulation of gene expression in small tissue samples. Analytical Biochemistry 245 141-148.

Auboeuf D, Rieusset J, Fajas L, Vallier P, Frering V, Riou JP, Staels B, Auwerx J, Laville M \& Vidal H 1997 Tissue distribution and quantification of the expression of $\mathrm{mRNAs}$ of peroxisome proliferator-activated receptors and liver $\mathrm{X}$ receptor-alpha in humans: no alteration in adipose tissue of obese and NIDDM patients. Diabetes 46 1319-1327.

Beshyah SA, Henderson A, Niththyananthan R, Skinner E, Anyaoku V, Richmond W, Sharp P \& Johnston DG 1995 The effects of short and long-term growth hormone replacement therapy in hypopituitary adults on lipid metabolism and carbohydrate tolerance. Journal of Clinical Endocrinology and Metabolism 80 356-363.

Beylot M, Khalfallah Y, Riou JP, Cohen R, Normand S \& Mornex R 1986 Effects of ketone bodies on basal and insulin-stimulated glucose utilization in man. Journal of Clinical Endocrinology and Metabolism 63 9-15.

Borson-Chazot F, Serusclat A, Kalfallah Y, Ducottet X, Sassolas G, Bernard S, Labrousse F, Pastene J, Sassolas A, Roux Y \& Berthezene F 1999 Decrease in carotid intima-media thickness after one year growth hormone $(\mathrm{GH})$ treatment in adults with $\mathrm{GH}$ deficiency. Journal of Clinical Endocrinology and Metabolism $\mathbf{8 4}$ 1329-1333.

Bulow B \& Erfurth EM 1999 A low individualized GH dose in young patients with childhood onset GH deficiency normalized serum IGF-I without significant deterioration in glucose tolerance. Clinical Endocrinology 50 45-55.

Carroll PV, Christ ER, Bengtsson BA, Carlsson L, Christiansen JS, Clemmons D, Hintz R, Ho K, Laron Z, Sizonenko P, Sonksen PH, Tanaka T \& Thorne M 1998 Growth hormone deficiency in adulthood and the effects of growth hormone replacement: a review. Journal of Clinical Endocrinology and Metabolism 83 382-395.

Chomczynski P \& Sacchi N 1987 Single step method of RNA isolation by acid guanidinium thiocyanate-phenol-chloroform extraction. Analytical Biochemistry 162 156-159.

Christopher M, Hew FL, Oakley M, Rantzau C \& Alford F 1998 Defects of insulin action and skeletal muscle glucose metabolism in growth hormone-deficient adults persist after 24 months of 
recombinant human growth hormone therapy. Journal of Clinical Endocrinology and Metabolism 83 1668-1681.

Damsbo P, Vaag A, Hother-Nielsen O \& Beck-Nielsen H 1991 Reduced glycogen synthase activity in skeletal muscle from obese patients with and without type 2 (non-insulin-dependent) diabetes mellitus. Diabetologia 34 239-245.

DeFronzo RA, Tobin JD \& Andres R 1979 Glucose clamp technique: a method for quantifying insulin secretion and resistance. American Journal of Physiology 237 E214-E223.

Ferrannini E 1988 The theoretical bases of indirect calorimetry: a review. Metabolism 37 287-301.

Fowelin J, Attvall S, Lager I \& Bengtsson BA 1993 Effects of treatment with recombinant human growth hormone on insulin sensitivity and glucose metabolism in adults with growth hormone deficiency. Metabolism 42 1443-1447.

Francis SM, Enerback S, Moller C, Enberg B \& Norstedt G 1993 A novel in vitro model for studying signal transduction and gene regulation via the growth hormone receptor. Molecular Endocrinology 7 972-978.

Fried SK, Russell CD, Grauso NL \& Brolin RE 1993 Lipoprotein lipase regulation by insulin and glucocorticoid in subcutaneous and omental adipose tissues of obese women and men. Journal of Clinical Investigation 92 2191-2198.

Hew FL, Koschmann M, Christopher M, Rantzau C, Vaag A, Ward G, Beck-Nielsen H \& Alford F 1996 Insulin resistance in growth hormone-deficient adults: defects in glucose utilization and glycogen synthase activity. Journal of Clinical Endocrinology and Metabolism 81 555-564.

Ho KK, O'Sullivan AJ \& Hoffman DM 1996 Metabolic actions of growth hormone in man. Endocrine Journal 43 S57-S63.

Horber FF, Marsh HM \& Haymond MW 1991 Differential effects of prednisone and growth hormone on fuel metabolism and insulin antagonism in humans. Diabetes 40 141-149.

Hwu CM, Kwok CF, Lai TY, Shih KC, Lee TS, Hsiao LC, Lee SH, Fang VS \& Ho LT 1997 Growth hormone (GH) replacement reduces total body fat and normalizes insulin sensitivity in $\mathrm{GH}-$ deficient adults: a report of one-year clinical experience. Journal of Clinical Endocrinology and Metabolism 82 3285-3292.

Jap TS, Ho LT \& Won JG 1989 Insulin secretion and sensitivity in hyperthyroidism. Hormone and Metabolic Research 5 261-266.

Jorgensen JO, Vahl N, Hansen TB, Thuesen L, Hagen C \& Christiansen JS 1996 Growth hormone versus placebo treatment for one year in growth hormone deficient adults: increase in exercise capacity and normalization of body composition. Clinical Endocrinology 45 681-688.

Kratzsch J, Blum WF, Schenker E, Keller E, Jahreis G, Haustein B, Ventz M \& Rotzsch W 1993 Measurement of insulin-like growth factor I (IGF-I) in normal adults, patients with liver cirrhosis and acromegaly: experience with a new competitive enzyme immunoassay. Experimental and Clinical Endocrinology 101 144-149.

Krotkiewski M, Seidell JC \& Bjorntorp P 1990 Glucose tolerance and hyperinsulinaemia in obese women: role of adipose tissue distribution, muscle fibre characteristics and androgens. Journal of Internal Medicine 228 385-392.

Laville M, Auboeuf D, Khalfallah Y, Vega N, Riou JP \& Vidal H 1996 Acute regulation by insulin of phosphatidylinositol-3-kinase, Rad, Glut4, and lipoprotein lipase mRNA levels in human muscle. Journal of Clinical Investigation 98 43-49.

Lefebvre AM, Laville M, Vega N, Riou JP, van Gaal L, Auwerx J \& Vidal H 1998 Depot-specific differences in adipose tissue gene expression in lean and obese subjects. Diabetes 47 98-103.
O'Neal DN, Kalfas A, Dunning PL, Christopher MJ, Sawyer SD, Ward GM \& Alford FP 1994 The effect of 3 months of recombinant human growth hormone $(\mathrm{GH})$ therapy on insulin and glucose-mediated glucose disposal and insulin secretion in GH-deficient adults: a minimal model analysis. Journal of Clinical Endocrinology and Metabolism 79 975-983.

Oscarsson J, Ottosson M, Johansson JO, Wiklund O, Marin P, Bjorntorp P \& Bengtsson BA 1996 Two weeks of daily injections and continuous infusion of recombinant human growth hormone (GH) in GH-deficient adults. II. Effects on serum lipoproteins and lipoprotein and hepatic lipase activity. Metabolism 45 370-377.

Oscarsson J, Ottosson M \& Vikman-Adolfsson K 1999 GH but not IGF-I or insulin increases lipoprotein lipase activity in muscle tissues of hypophysectomised rats. Journal of Endocrinology 160 247-255.

Page RC, Levy J \& Turner RC 1994 Obesity associated insulin resistance occurs in hypopituitary subjects. Diabetic Medicine $\mathbf{1 1}$ 862-865.

Pendergrass M, Koval J, Vogt C, Yki-Jarvinen H, Iozzo P, Pipek R, Ardehali H, Printz R, Granner D, DeFronzo RA \& Mandarino LJ 1998 Insulin-induced hexokinase II expression is reduced in obesity and NIDDM. Diabetes 47 387-394.

Reaven GM 1988 Role of insulin resistance in human disease. Diabetes 37 1595-1607.

Richelsen B 1999 Effect of growth hormone on adipose tissue and skeletal muscle lipoprotein lipase activity in humans. Journal of Endocrinological Investigation 22 10-15.

Richelsen B, Pedersen SB, Borglum JD, Moller-Pedersen T, Jorgensen J \& Jorgensen JO 1994 Growth hormone treatment of obese women for 5 wk: effect on body composition and adipose tissue LPL activity. American Journal of Physiology 266 E211-E216.

Rosen T \& Bengtsson BA 1990 Premature mortality due to cardiovascular disease in hypopituitarism. Lancet 336 285-288.

Salomon F, Cuneo RC, Umpleby AM \& Sonksen PH 1994 Interactions of body fat and muscle mass with substrate concentrations and fasting insulin levels in adults with growth hormone deficiency. Clinical Sciences 87 201-206.

Schalin-Jantti C, Yki-Jarvinen H, Koranyi L, Bourey R, Lindstrom J, Nikula-Ijas P, Franssila-Kallunki A \& Groop LC 1994 Effect of insulin on GLUT-4 mRNA and protein concentrations in skeletal muscle of patients with NIDDM and their first-degree relatives. Diabetologia 37 401-407.

Seidell JC, Bjorntorp P, Sjostrom L, Kvist H \& Sannerstedt R 1990 Visceral fat accumulation in men is positively associated with insulin, glucose, and C-peptide levels, but negatively with testosterone levels. Metabolism 39 897-901.

Vidal H, Auboeuf D, De Vos P, Staels B, Riou JP, Auwerx J \& Laville M 1996 The expression of ob gene is not acutely regulated by insulin and fasting in human abdominal subcutaneous adipose tissue. Journal of Clinical Investigation 98 251-255.

Weaver JU, Monson JP, Noonan K, John WG, Edwards A, Evans KA \& Cunningham J 1995 The effect of low dose recombinant human growth hormone replacement on regional fat distribution, insulin sensitivity, and cardiovascular risk factors in hypopituitary adults. Journal of Clinical Endocrinology and Metabolism 80 153-159.

Received 14 March 2001

Accepted 12 July 2001 